Марко Чудић

Универзитет у Београду

Филолошки факултет

marko.cudic@gmail.com

https://doi.org/10.18485/ai_san_o_gradu.2019.ch8

821.511.141.09-31 Сабо Л.

\title{
СЛИКА БЕОГРАДА У ПУТОПИСУ ЛАСЛА Ч. САБА
}

Путопис Ласла Ч. Саба (Cs. Szabó László, 1905-1984) из 1939. године, приказује Београд у предвечерје Другог светског рата, у пролеће 1939. године. У овом, по много чему запањујуће актуелном есејистичком штиву, овај врхунски интелектуалац и каснији велики емигрант мађарске књижевности, даје прилично суморну, стереотипима обојену слику Београда, Срба и Југославије. У раду који следи, овај путопис сагледава се из перспективе односа према Другом, уз посебан осврт на увек неуралгичну тему међусобних односа суседних народа и култура на овим просторима.

Кључне речи: путопис, суседне културе, однос према Другом, стереотипи.

Многи су се мађарски интелектуалци разних провенијенција огледали и у жанру путописа, а неки од њих нашли су за сходно да опишу не само своја путешествија у далеке, егзотичне пределе и Западну Европу, већ и у земље својих првих суседа. Кад је реч о двадесетом веку, своја путовања у Србију и Југославију, у краћим текстовима, овековечили су, између осталог, и веома познати књижевници као што су Игнотус (Ignotus, грађанско име Veigelsberg Hugó, 1869-1949), дугогодишњи уредник култног модернизаторског и еманципаторског књижевног часописа Nyugat (Запад), затим 
велики писац и песник Деже Костолањи (Kosztolányi Dezső, 1885-1936), који је свој први, младалачки путопис, посветио управо опису Београда, и то у тексту из 1909. године под насловом „Belgrádi képek“ („Београдске слике“), али и врсни, мада нешто мање слављени писац који ће касније постати препознатљиво књижевно име мађарске емиграције у Лондону, Ласло Ч. Сабо (Cs. Szabó László, 1905-1984). Тема овог рада јесте путопис управо овог последњепоменутог аутора, настао у предвечерје Другог светског рата, 1939. године, под насловом „Београдски јорговани“ из ауторове збирке путописа Fegyveres Európa (Наоружана Европа).

За разлику, међутим, од култног аутора Костолањија, чији је опус обрађиван из разноразних аспеката, и чија дела управо излазе у критичким издањима, Ласло Ч. Сабо, као писац који, по општем уверењу мађарских књижевних канонотвораца, по квалитету припада тзв. „другом ешалону“ писаца, ни поетички ни књижевноисторијски није довољно обрађен. У том смислу, чак и просечном мађарском читаоцу, а некмоли српском, потребна је кратка биографска скица, дакле, једна врста старинског, позитивистичког пролога, да би се уоквирило оно о чему ће у овом тексту бити речи.

Начелно, живот и стваралаштво Ласла Ч. Саба дели се на две фазе: мађарску (условно речено, младалачку) и емигрантску (условно речено, зрелу). Већ у Мађарској Ч. Сабо се афирмисао као писац и активни учесник у књижевном животу. Његово грађанско, лево-центристичко идеолошко опредељење осликава и чињеница да је био активни и плодни сарадник већ поменутог часописа Nyugat, али и часописа Magyar Csillag (Мађарска звезда). У периоду од 1935. до 1944. године био је уредник књижевног програма Мађарског радија; одиграо је важну улогу у упознавању шире публике са делима сав- 
ремених мађарских аутора. Чињеница да је 1936. године добио престижну Баумгартенову награду показује да је и те како направио себи име у књижевном животу предратне Мађарске. Емигрирао је 1949. године, прво се настанивши у Фиренци, да би од 1952. године живео у Лондону, где постаје сарадник Би-Би-Сија.

Штури подаци не могу нам много помоћи у поетичкој анализи Ч. Сабових дела. Новији лексикони, уосталом, свесно се суздржавају од аналитичких пасажа. Међутим, са старијим лексиконима то није случај. То посебно важи за тротомни Мађарски књижевни лексикон (Magyar Irodalmi Lexikon) из 1965. године. У одредници о Ч. Сабу, аутори, осим објективног навођења података о животу и делу овог писца, ипак се у једном тренутку нису суздржали од вредносног и, наравно, ондашњом владајућом идеологијом обојеног суда. Иако потпуно превазићен, овај став о његовом деловању из емиграције, данас може бити нарочито занимљив савременом читаоцу. Вредело би га стога нешто дуже цитирати:

У годинама хладног рата ни он није био кадар да сачува неутралност (и независност), појединим својим текстовима придружио се пропагандном рату против социјалистичког режима. Његове приповетке, романе, есеје, путописе и дневнике одликује разигран и префињен израз, дубоки лиризам, песнички романтичан начин приповедања, европско образовање које, истина, није лишено једностраности и елемената грађанске културе. [...] Више његових текстова инспирисано је мађарском судбином и представом о националној мисији Мађара, те њиховој жељи да се интегришу у Европу, али решења која он нуди више су духовноисторијске конструкције и песимистичке синтезе, него реалне анализе ситуације. (Benedek, Bölöni и др. 1965: 120) 
Извесна симболика путописа Ласла Ч. Саба крије се и у томе што је овај путопис о Београду настао тачно тридесет година након Костолањијевог. ${ }^{1}$ Иначе, оба путописа одликује не претерано благонаклон однос према ономе што виде, према људима са којима се сусрећу и према култури на коју наилазе. Тај, у најмању руку неблагонаклон однос вероватно проистиче што из нарцизма малих разлика, што из неког (пост)империјалног набоја који аутори не могу сасвим да сузбију у себи. Али ипак и са једном великом историјском, контекстуалном разликом: док Костолањи пише из перспективе Аустроугарске, у предвечерје Балканских ратова (1909), где прва реченица његовог путописа заиста представља историјски објективан исказ: „Воз за осам минута стиже од мађарске границе до Београда. Време недовољно да човек на миру попуши цигару“ (Kosztolányi 1996: 11), дотле Ласло Ч. Сабо у свом путопису (1939) пише из перспективе „крње“, „окрњене“, посттријанонске Мађарске, која је за пораз у Великом рату кажњена одузимањем великог дела теориторија. Његов постимперијализам, дакле, у најбољем случају могао би бити тек иредентистички и реваншистички, што он, на срећу, ипак није; тај се (пост)империјализам сублимира у неку врсту експлицитно неисказаног, али свудприсутног културног империјализма, у виду,

1 О Костолањијевом путопису писао сам у другом раду (видети Чудић 2006: 599-610)

2 Према слову Тријанонског споразума од 24. јуна 1920. године, Мађарска је, као сила губитница у Првом светском рату, изгубила око две трећине својих дотадашњих територија, а велики део Мађара преко ноћи се нашао у незахвалној позицији потлачене националне мањине у суседним државама. Тријанонска траума у свести многих мађарских родољуба и даље представља један од најтежих историјских удараца које је мађарска нација доживела. 
што оправданог, што мање оправданог, осећања властите културне надмоћи.

Овај, без сумње помало потцењивачки однос није, међутим, никакав мађарски изум; он представља средњоевропски рефлекс устаљених западњачких стереотипа у којима се Балкан посматра као, како Марија Тодорова наглашава, „кмет Европе, као њена тамна страна, антицивилизација, као алтерего, као застрашујуће изобличени одраз у огледалу“ (Тодорова 1999: 324). У том смислу, како би рекао Кристијан Ђордано, „менаџери идентитета“ (у овом случају балканског), „продуценти идентитета“, „идентитетски археолози“ (Ђордано 2001: 220) били су ранији западни путописци, а неки елементи таквог стереотипног виђења касније су се запатили чак и код писаца из земље наших непосредних суседа.

За разлику, међутим, од Костолањијевог путописа, веома живог, вибрантног, са мноштвом описа и асоцијативних слика, са честим поређењем одређене ситуације са сличним ситуацијама у домовини, путопис Ласла Ч. Саба много је сведенији, економичнији, „сувљи“, са мање путничке деиксе, а више есејистичких пасажа са врло особеном анализом историјских околности, уз препричавање путопишчевих разговора са његовим образованим саговорницима и домаћинима, али и са више наноса публицистике. Све то путопис Ласла Ч. Саба чини знатно мање поетичним од Костолањијевог. Читалац понекад чак има осећај да чита некакав историјско-публицистички трактат. За разлику од Костолањија, који импресионистички бележи случајно ухваћене слике, које затим у њему покрећу лавину асоцијација, често врло иронично интонираних, дотле се Ч. Сабо не осврће превише на детаље; напротив, склонији је томе да општим потезима 
ослика-скицира ширу слику и да се прилично смело, са готово фељтонистичким жаром, упусти у анализу актуелне политичке ситуације. Код њега никада не бисмо могли прочитати, нпр. готово песничку импресију да му Београд делује као спој веселог Медитерана, југа, и туге и меланхолије руских степа и руских романа, као што то читамо код Костолањија (Kosztolányi 1996: 11, 12).

Напротив, Ласло Ч. Сабо у свом дневничкоесејистички интонираном путопису, повлачи општије, историјске паралеле, у којима проклетство нулте године, односно стална, углавном споља, злехудим околностима наметнута нужност појединим народима да кроз историју прилично често крећу испочетка, задобија важно место. Наиме, Ч. Сабо луцидно примећује: „Историја Србије, баш као и наша, кренула је испочетка после Турака. За њен наставак треба скочити од византијских фресака до Наполеоновог доба. Тада опет излази на видело српска историја. Тектонски расцеп који називамо Француском револуцијом и ову је понорницу ослободио из стена“ (Cs. Szabó 1939: 24)33.

Слично Костолањију, а вероватно делимично и под утицајем званичне политике и пропаганде своје домовине у то време, и Ласло Ч. Сабо главне разлоге

3 Иако се овде наводе странице оригиналног текста, важно је напоменути да је још необјављени превод (чију донекле модификовану верзију овде цитирамо) дело колективног напора садашњих и некадашњих студената хунгарологије на Филолошком факултету у Београду, поименце Ане Балог, Мине Мастиловић, Габријеле Нађ, Кристине Пејановић и Саре Рокаи, а у оквиру српског преводилачког семинара, одржаног, под руководством и менторством Марка Чудића, у „Кући мађарских преводилаца“ (Magyar Fordítóház) у мађарском граду Балатонфиреду, у периоду од 10. до 17. септембра 2018. године (видети у Изворима). 
чињенице да се Србија и Мађарска већ дуже време налазе на супротстављеним странама глобалних политичких интереса, види у мешању Русије у овдашње политичке прилике (и Мајски преврат тумачи као знак заокрета српске спољне политике према Русији).

За разлику, међутим, од Костолањија, који, као млад човек и новинар, долази у Београд, у то време, 1909. године, још несумњиву паланку која у односу на сјај и раскош империјалне Будимпеште уопште и не подсећа на било какву престоницу, па отуда извлачи и недвосмислен закључак о апсолутној супериорности мађарске културе и духа у односу на српски, Ч. Сабо веома (само)критички посматра хронични мађарски комплекс више вредности у односу на своје непосредне балканске суседе: ${ }^{4}$

4 Иако је велики део становништва Угарске, у периоду после слома Револуције 1848. године, а пре Нагодбе са Хабзбурзима 1867. године, подржавао непризнату владу у егзилу вође револуционара Лајоша Кошута (Kossuth Lajos, 1802-1894), када је 1862. године обелодањена Кошутова идеја Дунавске конфедерације малих средњоевропских и балканских држава као противтежа хегемонији Беча, чак су се и неки најзагриженији мађарски суверенисти нашли увређени што се нашао неко ко би желео да на равној нози разговара са, како су они сматрали, државама и народима на цивилизацијски нижем нивоу. Тај би се својеврсни културни расизам могао сажети у крилатици „Боље Беч, него Београд или Букурешт“ (Кósa 1993: 284). Иначе, та Кошутова (нажалост, одоцнела) идеја о Дунавској конфедерацији, могла би се схватити и као нека врста Кошутовог накнадног покајања и признања да би побуна против Беча из 1848. године, која је 1849. године прерасла у прави крвави рат, вероватно имала много повољнији исход по Мађаре и Мађарску, да је он, као вођа Револуције, имао више слуха за захтеве мањина (односно народности, како су их тада у Угарској звали). У том случају, народности се вероватно не би окренуле Бечу у гушењу мађарског устанка. 
У домаћем билансу Нагодбе 5 добро и лоше још се некако и боре. Али у очима света, она нам је само нашкодила. Ако смо у глави једног просечног западњака и дан данас варвари немачког матерњег језика, мађарофони Аустријанци или неке сличне наказе, разлог томе је Нагодба. Избора немамо, у очима света или смо народ Св. Иштвана, Ракоција и Кошута или безимени народ. Трећег пута нема.

Највећу шттету нам је Нагодба донела у Подунављу. Мађарски народ је сујетан народ, он себе сматра изврснијим од својих суседа. И био је. Изврснији, али не и другачији. Немањићи су својевремено послали принцезу у кревет Арпадовића, мађарски и српски витезови били су на истој страни, на бојиштима старе Србије.

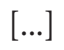

Наш је језички национализам још почетком прошлог века снажно подривао ту слогу. [Лајош] Кошут се непромишљено огрешио о народности. Да смо остали заједно, можда смо могли све да изгладимо. Са Нагодбом, међутим, постали смо саучесници у угњетачкој балканској политици, дали смо војнике за подухвате који су Арпадовићи и Анжујци у посве другим околностима и са сасвим другачијим исходом једном већ извршили. У самој држави, прави Мађари-дођоши, леђима ослоњени на дуалну монархију, латили су се мађаризације, којој се, да није било Нагодбе, никада не би ни латили. (Cs. Szabó 1939: 27-28)

Важан елемент сваког путописа јесте и то да ли се путописац упушта у дијалоге са „локалцима“, те ко су му саговорници, да ли тзв. „обични људи“, сељаци, грађани, политичари, новинари или, рецимо, интелектуалци у најширем смислу. Ласло Ч. Сабо у овом пу-

5 Мисли се, дакако, на Аустро-Угарску Нагодбу из 1867. године, која је, након Баховог апсолутизма, представљала неку врсту компромиса између мађарских суверенистичких тежњи и хабзбуршког империјализма. 
топису именује двојицу својих српских саговорника, истина, означава их само иницијалима (В. П, односно С. Ст.), али на основу њихових портрета̂ које нам даје, те чињенице да је реч о Србима-Пречанима који савршено говоре мађарски језик, сасвим је јасно да је реч о Вељку Петровићу и Светиславу Стефановићу. Вељко Петровић, чак, Ласлу Ч. Сабу служи и као нека врста духовног водича кроз српску ситуацију:

В. П. је из Бачке. Мађарски му служи као језик дипломатије. Понекад тражи речи из Пазмањевог 6 доба, оне последње језичке реформе ${ }^{7}$ нису му довољно оштре, нису довољно сочне за српски укус. А често ни за мађарски! Али неко ко тако изврсно влада нашим језиком чак је и на другој страни земљине кугле наш роб. Дошао је из Бачке у Пешту да постане правник, учествовао је у студентским демонстрацијама. Тамо је увидео колико је исцеђена и неуравнотежена миленијумска Мађарска ${ }^{8}$. Са шљаштећег базара вратио се у сељачку варошицу.

Још увек га занимају и раздражују Мађари, не може да се одвикне од њих. Припадник је старе генерације, једном ногом још у ancient regime-у Аустроугарске. „Зашто Мађар увек гледа на Запад? Стално је пренапрегнут, отуд то узбуђење и несаница. Нек погледа мало око себе! Србин га више цени него нпр. Енглез. Истина, улога

6 Петер Пазмањ (Pázmány Péter, 1570-1637), естергомски надбискуп и писац, велика фигура мађарске противреформације. Ово je, заправо, велики комплимент за Вељка Петровића, јер рећи за једног немађара да говори Пазмањевим језиком, представља врхунско признање његовом језичком умећу.

7 Језичке реформе с краја осамнаестог и почетка деветнаестог века, под вођством Ференца Казинција (Kazinczy Ferenc, 1759-1831).

8 Мађари су 1896. великом (светском) изложбом и изградњом многобројних атракција, поготово у Будимпешти, обележили хиљадугодишњицу свог доласка и насељавања у Карпатски басен. Тада је, поред осталог, изграђена и Миленијумска кула у Земуну, код нас познатија као Кула Сибињанин Јанка. 
подунавског народа није толико допадљива као улога западног народа.“ Оштар језик има наш пријатељ. (Cs. Szabó 1939: 29)

Посебно је занимљив Ч. Сабов прави мали трактат у којем анализира српско-хрватске односе који су 1939. године већ били на ивици пуцања. У анализу, поред констатовања актуелно-политичке ситуације (Шестојануарска диктатура, пад Стојадиновићеве владе, итд.), он уводи компаративне аспекте и цивилизацијска поређења, не само у мађарском, већ и у ширем, европском контексту. Иако несумњиво једностран и „навијачки“, овакав приступ занимљив је утолико што не извире из тада актуелних расистичких теорија, већ би се пре могло рећи да представља претечу и мини-верзију нечега што ће, много касније, тек поткрај двадесетог века, Хантингтон назвати „ратом цивилизација“. Непомирљивост ових светова Ч. Сабо, наравно, види у конфесионалним разликама, но, да би се разумео ток његових мисли, овде је неопходно дати нешто дужи цитат (чак и смирени Вељко Петровић приказан је као човек који на помен српско-хрватског спора лако губи живце и плане):

Као што се иза француско-бретонског спора крије један древнији латинско-келтски сукоб, тако и у српскохрватском спору ратују Византија и Рим. Оваква легура распала би се и у најјачем обручу. Сетимо се само Ердеља [Трансилваније]. Узалуд је румунски језик изникао из латинског корена, ердељска слобода три језика и четири вероисповести увек би устукнула на прагу Византије, коју није могла прихватити. Права опасност за Ердељ било је то што је источна ортодоксија, тј. Византија почињала међу њеним зидинама, а не источно од Брашова.

А у Југославији је, међутим, управо Рим, преко Хрватске и Далмације доспео међу византијске зидине. 
А Аустроугарску су у оно време италијанска Истра и хрватска Далмација учиниле медитеранском. И међу њеним војницима који су поразили Турке, хрватски војници били су католички витезови првог реда. Између далматинског рибара и млетачког дужда већа је сличност него између тог истог рибара и, рецимо, тамо неког сељака из Ниша. Хрвати су се дистанцирали од италијанске латинштине и римокатоличанства, али им се велики део тога наталожио у души, вековима је усмеравао свест о њиховој мисији, баш као и код Мађара. Ако уклониш илирски национализам из XIX века (Наполеоново увозно духовно средство за разбијање Хабзбуршке империје), под њим ће да блесне заједнички идеал Зрињског и Дубровчанина Гундулића. Југославија је ујединила српски и хрватски народ. Али, тек што је колико-толико задовољен илирски национализам, из националисте XIX века избио је древнији Хрват са својим млетачким, бечким и мађарским сећањем.

$$
[\ldots]
$$

Срби завиде Хрватима, иритира их њихова културна надмоћ, а опет, Хрвати гледају на Србе из позиције своје културне надмоћи „Загреб: une ville finie“, раздражено каже В. П. „Иначе и ми смо народ подједнако стар као и Хрвати и Мађари. Погледајте једном грачаничке фреске на Косову Пољу 9 . Југославија је једино савршена у данашњем облику. Хуманизам Дубровника и Загреба допуњује народна и манастирска култура Јужне Србије иза које су остали средњовековни споменици, све један лепши од другога.“ То је управо то! Српска култура дубоко је прожета Византијом. В. П. спаја Рим и Византију и у ово двоје види само културну раслојеност на хуманистичку културу и дубоку народну културу. Разумљиво је то. Борио се против нас, духовно и психолошки брани овај status quo.

$$
[\ldots]
$$

9 Управо овако пише у тексту путописа. Као преводиоци текста, нисмо сматрали да по сваку цену морамо да исправљамо путопишчеве историјске и топографске непрецизности. 
Хабзбуршка традиција међу Словенцима и Хрватима је чак и без Хабзбурга моћна алатка у рукама Немаца. Срби и Хрвати су сатерани у ћошак, преговарају од раног пролећа. (Cs. Szabó 1939: 30-32)

Ретко који странац, путник-намерник је 1939. године имао оволико нијансирану слику о тињајућем конфликту два највећа јужнословенска народа. А понекад нам је и те како потребно страно огледало, ма колико било неповољно за нашу, по дефиницији, нарцистичну слику о самима себи. Тек из данашње перспективе може се сагледати сва далековидост једног оваквог увида. Савремени српски историчар новије генерације, Миливој Бешлин, о чињеници да су конфликти у првој Jугославији напросто били неизбежни, каже следеће: „Југословенско уједињење изведено је прекасно да би њени кључни етницитети могли бити сливени у једну нацију, слично Немцима и Италијанима, али је и настала прерано да би се разумела и усвојила историјска неминовност о довршеном процесу конституисања три различита народа: Срба, Хрвата и Словенаца“ (Бешлин 2018).

За разлику од Вељка Петровића, ствараоца у напону снаге и најбољим годинама, Светислава Стефановића, иако свега десет година старијег од Петровића, путописац доживљава као резигнираног старца и својеврсног смиреног мудраца, ерудиту који верује да би управо мађарска култура могла да одигра улогу некаквог посредника између великих западноевропских култура и Срба:

Код С. Ст. Тихи, седокоси човек, трећи по реду српски преводилац Мадача ${ }^{10}$, кажу, и најбољи. Већ

10 Имре Мадач (Madách Imre, 1823-1864), велики драмски писац XIX века, аутор Човекове трагедије (Az ember tragédiája). 
деценијама преводи Шекспирова сабрана дела (чије име пишу ћирилично и фонетски), која се управо штампају. Човек очима странца непрестано учи о својој домовини. Тек се сада примећује да се и данас у Шекспировој „другој домовини“ играју комади на основу збрзаних, али преко потребних превода из седамдесетих и осамдесетих година. ${ }^{11}$ Премда је вечита предност преведеног Шекспира над оригиналом управо у томе што је стално нов и допире и до неуких. Освештан оригинални текст прогони га међу образоване, некадашњи велики забављач, упркос својој тровековној старости, тавори испод свог нивоа. У иностранству се пак увек изнова спушта међу народ и остаје онакав каквим су га његови домаћи савременици видели. Код куће је прикован за умируће елементе језика, док у туђини може било када да се ослободи застарелог или претерано класичног превода. (У Немачкој нпр. од Тика и Шлегела.)

[...] Зна све о мојој генерацији, требало је да дођем у Југославију, да би она била спомињана без злобе. Код куће у књижевно-политичкој игри црвених рукавица бледи чак и величина једног Атиле Јожефа.

Разговор скреће у неочекиваном правцу: „Жао ми је што наши млади слабо познају мађарску омладину, па уче од Француза. Мађари су веома вешти у препевавању, западњаштво код њих има вишевековну традицију па су 'наклоњени страном', а опет тако старински и мађарски. Штета би било пропустити ово мађарско посредовање, српство би у свом корену остало много више српско посредством једне француско-мађарске културе него кроз чисто француску.“ (Cs. Szabó 1939: 33-35)

Није, међутим, само књижевна уметност кадра да трансцендира националне и менталитетске границе. Овако Ч. Сабо види скулпторско умеће Ивана Мештровића:

11 Ово је жаока упућена Мађарима и Мађарској. Наиме, Мађари су дуго ласкали себи да је управо Мађарска била „Шекспирова друга домовина“. 
Скулптуре Ивана Мештровића. Велики уметник малог народа способан је да своју грану уметности претвори у израз нације. Од Торвалдсеновог времена вајарство предњачи међу скандинавским уметностима. Засад Мештровића сматрају само Далматинцем, а не Југословеном; он је своју медитеранску архаизацију научио од Француза, а у његовом сељачком католичанству више би задовољства нашао Св. Амброзије него Ћирило и Методије. На њега је снажно утицала и сецесија с краја века, барем онолико колико и на Едена Лехнера у његовој грани уметности. Можда ће га зуб времена једног дана претворити у заједнички израз духа Јужних Словена и у њему ће се стопити Рим са Византијом. За сада га само Средоземно Море и крај века могу сматрати својим.

Али током овог преображаја време ће га највероватније очерупати. Мештровић је изузетно велики скулптор, али насилан и пророчког духа, као и сваки уметник који не говори само у своје име већ и у име некакве магловите народне душе. (Cs. Szabó 1939: 36 -37)

Ипак, упркос овом излету у уметност, путопис мађарског писца завршава се темама којима је и започет - историјом и политиком. Но, помиритељски тонови као да све више преовлађују како се путопис ближи крају. А све то уоквирено је призором јоргована у цвату. Уместо закључка и завршног акорда овог чланка, који у случају оваквог хетерогеног и у доброј мери импресионистички интонираног путописа, тешко да би и могао бити поуздано донет, нека овде поново стоји нешто дужи цитат:

Тврђава је прекривена јоргованима у цвату. Жури им се више него нашима, на Гелертовом брду тек сада пупе.

Где год да погледам, вода господари. Тек се одавде стварно види колико само воде носе Дунав и Сава! Њихове боје благо се мешају. Прекрасан је овај полудивљи предео. Са друге стране реке, уместо Пеште, сребренка- 
сто шипражје умива се у реци. Тамо на малом савском острву проливена је прва мушка крв у Светском рату. Поново корачам бојним пољем Светског рата.

В. П. ми објашњава куле Еугена Савојског и успут се присећа витезова граничара који су тражили српске свештенике као знак да су се и овдашњи момци тукли под командом мађарског капетана. „Черупамо се и волимо као голубови.“ Овом галантном реченицом један забринути мали народ шаље поруку другом.<smiles>[CH]1[CH]C=C1</smiles>

Наше је доба Левијатан малих народа, још само један рат и пред њима ће се отворити гроб нација из визије Михаља Верешмартија. ${ }^{12}$

$$
[\ldots]
$$

Србија се на царев знак завадила са моћном Аустроугарском. Југославији прете већи губици. Над челом Срба надвио се облак који Мађаре већ одавно притиска. Помислимо на овај облак ако икада пожелимо да се помиримо са нашим јединим поштовања достојним противником.

Јорговани цветају, нежни мирис цвећа шири се пролећним ваздухом. Увече се из кафана ори босанска музика. Конобар доноси турску кафу која се пуши. Млади војници седе за суседним столом и са наивним осмехом посматрају певаљке. (Cs. Szabó 1939: 37-39)

\section{Извори и литература}

\section{Извори}

Kosztolányi Dezső. Elsüllyedt Európa. Útirajzok. [Потонула Европа. Путописи]. Budapest: Rejtjel Kiadó, 1996. Штампано

12 Михаљ Верешмарти (Vörösmarty Mihály, 1800 -1855), један од највећих песника мађарског романтизма, имао је апокалиптичну визију нестанка мађарске нације. 
Сабо, Ласло Ч. „Београдски јорговани“. Са мађарског превели Ана Балог, Мина Мастиловић, Габријела Нађ, Кристина Пејановић и Сара Рокаи. Рукопис.

Szabó László Cs. Fegyveres Európa. Útinaplók. [Наоружана Европа. Дневници са путовања]. Budapest: Nyugat, 1939. Штампано.

\section{Литература}

Benedek Marcell и др. Magyar irodalmi lexikon. Harmadik kötet

[Мађарски књижевни лексикон. Трећи том]. Budapest: Akadémiai Kiadó, 1965. Штампано.

Бешлин, Миливој. „Век Југославије. Наличје уједињења“. Доступно на сајту: http://avangarda.ba/detaljno.php?id=709. Веб 25. 12. 2018.

Ђордано, Кристијан. Огледи о интеркултурној комуникаuији. Превели са немачког и енглеског Томислав Бекић и Владислава Гордић. Београд: Библиотека XX века, 2001. Штампано.

Kósa László и др. A magyarságtudomány kézikönyve. [Приручник науке о мађарству/хунгарологије]. Budapest: Akadémiai Kiadó, 1993. Штампано.

Тодорова, Марија. Имагинарни Балкан. Превеле с енглеског Драгана Старчевић и Александра Бајазетов-Вучен. Београд. Библиотека XX век, 1999. Штампано.

Чудић, Марко. „Неки стереотипи о Балкану у краткој прози модерних мађарских писаца (Деже Костолањи и Ендре Кукорели)“. Кюижевна историја 130 (2006): 599-610. Штампано. 
Marko Čudić

\section{THE PICTURE OF BELGRADE IN LÁSZLÓ CS. SZABÓ'S TRAVELOGUE}

László Cs. Szabós (1905-1984) travelogue entitled "Belgrade Lilacs" from his book of travelogues Fegyveres Európa (Europe under Arms) gives a depiction of Belgrade not long before the outbreak of World War Two, in the spring of 1939. In this essayistic text, astonishingly up-to-date in many of its aspects, this top intellectual and later a great emmigrant figure of Hungarian literature, gives a gloomy depiction of Belgrade, the Serbs and Yugoslavia, which is full of stereotypes. The aim of this paper is to analyse this travelogue from the perspective of the relation towards the Other, with special emphasis on the ever neuralgic topic of the mutual relations of neighbouring nations and cultures in this region.

Keywords: travelogue, neighbouring cultures, relationship towards the Other, stereotypes. 